\title{
PATTERNS OF BEHAVIOUR IN THE MANAGER-EMPLOYEE RELATIONSHIP - THE RESULTS OF EMPIRICAL RESEARCH IN POLISH BUSINESS ORGANIZATIONS
}

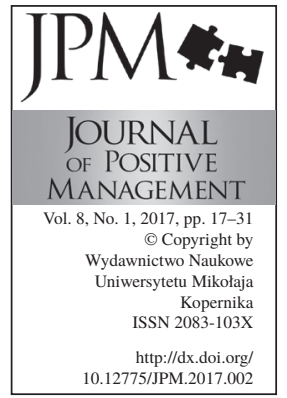

\author{
Izabela Bednarska-Wnuk \\ University of Lodz, Lodz, Poland \\ e-mail: iwnuk@uni.lodz.pl
}

\begin{abstract}
Purpose: The purpose of the article is to identify patterns of organizational behaviour for the manager-employee relationship and to identify differences in this respect depending on the position of the individual in the organizational structure against the background of the official business relationship on the basis of the empirical research in Polish business organizations.
\end{abstract}

Methodology/approach: The tool used in the study was a standardized WAZO questionnaire designed to examine organizational solutions and organizational behaviours, both from the general perspective and broken down to behavioural dimensions, conducted in 2015 on a representative randomly selected group of 2274 employees from 40 Polish companies.

Findings: Using a proprietary research questionnaire, three patterns of behaviour have been identified for the manager-employee relationship: traditional, contemporary and future, described by way of components such as the scope of power, power distance, the basis of the manager's power, the method of selection of information and the degree of stability of power. The obtained results indicate that in Polish organizations dominate contemporary behavioural patterns for the first four mentioned criteria, whereas for the last one - degree of stability of power, the dominant pattern of behaviour was the traditional pattern.

Implications/limitations: Empirical studies do not take into account all elements of behaviour from the perspective of power relations, due to research limitations. Nonetheless, characterising the behavioural patterns using various criteria is universal and widely used. In addition, research on this subject is very subjective - although the research tool was standardized, the results mainly depend on how people perceive their relationships with the authorities.

Originality/value: The article shows on the basis of the proprietary questionnaire the contemporary patterns of behaviour from the perspective of power relations, and recommendations for practice. Managers who know certain patterns of behaviour will be able to model employees' attitudes towards 
work and to shape relevant social relationships. As for employees, they may be inspired to modify their own behaviours, in accordance with the requirements of the organizational environment.

Keywords: organizational behaviour, human in the organization, relationship manager-employee

Paper type: Research paper

\section{Introduction}

The basis for the functioning of each relationship is its social relations. They are the building blocks of an organization, forming an internal network of formal and informal relationships. Many aspects of organization are also determined by employee relationships. These include: decision-making, information flow, organizational culture or human resources management practices (Rawlins, 1992). When trying to describe relationships between managers and employees, it is important to assume that their form and scope are diverse. On the one hand, we are dealing with a set of requirements and expectations addressed to employees and, on the other, with their actual behaviour.

The current trend in research in management related to the manageremployee relationship is usually focused on the background of power (Sikorski, 1999; Robbins and Judge, 2012; Ayache and Laroche, 2010). Researchers in this area analyze primarily: the manager's skills (tasks, duties, managerial roles, functions and their scope, structure of skills and personal attributes), and his or her leadership style (including decision making process, communication process, attitude to employees and the way of solving conflicts). It is also difficult to clearly state which aspects of organizational behaviour for the manager-employee relationships are decisive. Therefore, when trying to describe these relationships, one should remain at a certain level of generality which allows for formulating conclusions.

The study assumed that at the base of the development of certain behavioural patterns for the area of the manager-employee relationship there are, on the one hand, employee behaviours with respect to the manager, manifested in the way of carrying and pace of work, setting performance goals for employees and tasks being done. On the other hand, it is the realization of the managerial function and the manager's behaviours which influence the attitudes of employees. In order to describe these relationships, the considerations in this article are based on the WAZO concept - Multivariate Analysis of Organizational Behavior, which distinguishes three patterns of organizational behavior, defined as traditional, contemporary and future (Januszkiewicz, 2012).

The aim of the article is to identify patterns of organizational behavior for the manager-employee relationship and to identify differences in this regard depending on the position of the individual in the organizational structure against 
the background of the official business relationship on the basis of empirical research carried out in 2015 on a representative randomly selected group of 2274 employees from 40 Polish companies.

\section{Manager-employee relationships versus patterns of organizational behavior- theoretical approach}

Relations between managers and employees are a very important element in the organization. According to the research, it is much easier to overcome difficulties in a good working atmosphere. It is this support from the manager that determines the level of willingness to work and is related to the physical and mental conditions of the employee's work, thus remaining at the centre of staff management (Szałkowski, 2006).

These relationships may be considered by way of a variety of factors. On the basis of literature review, it seems that these relations are most often described in the context of:

- communication between managers and employees (O'leary and Pulakos, 2011),

- employee loyalty (Świątek-Barylska, 2013),

- the competencies of executives (Rakowska, 2007),

- organizational commitment of employees (Juchnowicz, 2012; Amarjits, 2008),

- trust (Lewicka, 2013).

One of the concepts combining these elements is the specific position of the individual, understood as the location of employees against the background of a specific organizational structure. It concerns the role of the official business relationship (Sikorski, 1999). With regard to manager-employee relationships, this role can be represented by such criteria as: source of power, the basis of manager's power, stability of power, scope of power, method of information selection and social distance between managers and employees (Sikorski, 1999). They influence patterns of organizational behaviour. These criteria (apart from identification of the source of power that was not subject to research) have become the subject of this paper, thus differentiating patterns of behavior. They are shaped in space of the organizations by two entities: managers and employees. As this space undergoes dynamic changes, we deal, in consequence, with the evolution of an organization which contributes to diverse patterns of behaviour. In order to describe such a complex phenomenon, the considerations in this paper are based on the WAZO concept - Multivariate Analysis of Organizational Behavior, which distinguishes three patterns of organizational behavior, defined as traditional, contemporary and future (Januszkiewicz, 2012).

These patterns have become the basis for describing the relationships between managers and employees (Table 1).
PATTERNS OF BEHAVIOUR IN THE MANAGER-EMPLOYEE

Izabela Bednarska-Wnuk 
PATTERNS OF
BEHAVIOUR IN THE
MANAGER-EMPLOYEE

Izabela Bednarska-Wnuk

Table 1.

Components of superior-subordinate relationships versus patterns of organizational behavior

Source: authors' own elaboration.

\begin{tabular}{llll}
\hline \multirow{2}{*}{ Criterion } & \multicolumn{3}{c}{ Organizational behaviour } \\
\cline { 2 - 4 } Scope of power & Traditional & Contemporary & Future \\
\hline Power distance & High & Democratic & Affiliative \\
\hline $\begin{array}{l}\text { Basis of the mana- } \\
\text { ger's power }\end{array}$ & Formal authority & $\begin{array}{l}\text { Formal authority and } \\
\text { having specific com- } \\
\text { petencies }\end{array}$ & $\begin{array}{l}\text { Exclusively possessed } \\
\text { knowledge and skills } \\
\text { between mandaries } \\
\text { employees }\end{array}$ \\
\hline $\begin{array}{l}\text { Method of selecting } \\
\text { information }\end{array}$ & $\begin{array}{l}\text { Effectuated exclusive- } \\
\text { ly by the manager }\end{array}$ & $\begin{array}{l}\text { Effectuated partly } \\
\text { by the manager and } \\
\text { partly by the employee } \\
\text { himself }\end{array}$ & $\begin{array}{l}\text { Effectuated indepen- } \\
\text { dently by employees }\end{array}$ \\
\hline Stability of power & Permanent & Temporary & $\begin{array}{l}\text { Temporary -the so- } \\
\text {-called relay of roles }\end{array}$ \\
\hline
\end{tabular}

The characteristic feature of the traditional type of organizational behavior is the attitude towards the employee, and the task of the manager is to perform only managerial functions. The employee performs his or her duties primarily in a manner strictly defined by the manager. He does not feel like an important participant in the organizational process, but is the so-called cog in the machine. $\mathrm{He}$ is also characterized by lack of freedom and autonomy in the decisionmaking process, performing only the orders of the manager (absolute obedience). Managers are characterized by the need for dominance, and employees- by the need for security that can be satisfied by showing obedience to the managers. For behaviours of the traditional type, the relationship between managers and employees is based on unidirectional influence (Kożusznik, 2014), in which the scope of power is related to the subordination of employees. This corresponds to an asymmetric conception of power, according to which only the manager can formulate the proper goals of the action and determine the best ways of accomplishing them (Sikorski, 2009).

The basis of the manager's power is the formal authority, resulting from his particular position in the organization. The method of information selection is effectuated exclusively by the manager, and this stems from the belief that employees should be equipped only with knowledge that is important for achieving the organization's goals. The manager is therefore a peculiar "source of power" (Jabłoński, 2012) as well as ,the source of knowledge” (StańczykHugiet, 2010). 
The degree of stability of power in traditional behavior is permanent. This means that the manager fulfils his ,life-long" role on the basis of open-ended employment, which provides him with a sense of a long-term participation in the organization, giving him a guarantee of security.

Organizational behavior of the contemporary type is characterized by democratic relations between managers and employees. The employee and his potential is noticed, therefore, he is encouraged to be an independent and responsible individual (Sikorski, 1999) in decision-making. These relations are based on mutual trust that influences the decision-making process. The power distance is low. The manager recognizes the role of the employee in the organization and begins to treat him as an autonomous individual capable of independently collecting and selecting information about the organization.

The basis of the manager's power is not only a formal authority, as was the case with the traditional type, but it results primarily from having high qualifications and ethical values (Penc, 2007). The degree of stability of power in contemporary behaviour is characterized by temporality. This means that after performing a specific task, the power is "delegated" to another person indicated by the manager. The manager is hired by the organization most often for a definite time.

The changes taking place in the organization's space cause that the scope of relations between managers and employees change in the new conditions of its functioning. For the organizational behaviour of the future type characteristic is an afiliative scope of power. The manager departs from commanding, instructing and giving orders on behalf of motivating and encouraging employees to become independent in the decision-making process, while creating a friendly working environment. The power distance is low or visibly missing. The boundary between the managers and employees is blurred. This means full autonomy for workers in the work situation. They do not require direct supervision. The manager is also willing to share knowledge with employees, and the way information is selected is effectuated by the employee himself, who knows how and by what methods the necessary organizational knowledge needs to be obtained to effectively fulfil his roles in the organization.

The basis of the manager's power is not his formal authority, but the knowledge and skills that he possesses. The manager does not need to occupy a particular position in the organizational structure, and his power may result, for example, from delegation.

The way of stability of power is temporary and depends on the fulfilment of a particular task. It favours temporary and relay types of roles carried out by the manager, as well as the transition of power in the organization. This involves the increasingly frequent hiring the manager based on the Civil Code instead of the Labour Code, most often under a managerial contract.
PATTERNS OF BEHAVIOUR IN THE MANAGER-EMPLOYEE

Izabela Bednarska-Wnuk 
PATTERNS OF BEHAVIOUR IN THE MANAGER-EMPLOYEE

Izabela Bednarska-Wnuk

\section{Methodology of research}

This paper presents the results of a research project entitled "Multivariate Analysis of Organizational Behavior [WAZO] - methodology and measurement tool", conducted at the Department of Management of the University of Lodz [1].

Based on the thesis adopted in the article that the patterns of behavior differentiate relations between managers and employees, two hypotheses were put forward:

$\mathrm{H}$ 1: There is a relationship between patterns of behavior and the components that make up relationships between managers and employees.

H 2: In Polish organizations dominate contemporary behavior patterns in relations between managers and employees.

According to the assumptions, empirical research was conducted in two stages in 2015. The purpose of the first stage was to describe the organization (289 for-profit organizations participated in the survey), the purpose of the second stage was a description of the organizational behaviours of employees selected purposefully from the first stage, in which participated 2274 employees from 40 organizations, including $33.6 \%$ women and $60.2 \%$ of men (about $6 \%$ of the respondents did not give their gender) [2].

The average age of the subjects was 38.2 years ( $\mathrm{STD}=10.7$ years). Half of the employees were no more than 36 years old. The youngest was 15 and the oldest was $83.25 \%$ of people were no more than 30 years old; on the other hand $25 \%-$ not less than 45 years. Most represented were groups 25 to 24 years (27.6\%) and $35-44$ years $(24.4 \%)$, the least represented were the youngest group (under 25 years of age $-4.1 \%$ ) and a group of 55-year-olds+ (8\%). About one in four people did not give their age. Participants in the study are primarily employees with at least 2 years of placement. Almost every third person is employed for more than 10 years, every fourth - from 5 to 10 years, every fifth - between 2 and 5 years. Approximately $10 \%$ are people with up to one year of placement and another $10 \%$ - from one to two years of placement. The extrapolated value of the median of placement reaches 6.4 years (half of whom have not more than 6.4 years of placement).

The results presented in the article come from the first and second stages. The tool used in the study was the WAZO Questionnaire (developed by the team included in the project) (Januszkiewicz et al., 2016), designed to examine organizational solutions and organizational behaviours both in general and broken down into individual dimensions. The results of the research presented in this paper refer to one of the dimensions of organizational behavior defined as manager-employee relationship. The theoretical constructs distinguished in the model have been operationalized in empirical research using variables (the basis of manager's power, degree of stability of power, scope of power, the way of information selection, and social distance between managers and employees) 
regarding behavioural against the background of power relations. The independent variables that have adopted the explanatory variables status are behavioural patterns: traditional, contemporary, and future.

The chi-squared test was used to determine correlations and to test hypothesis, by means of a Pearson's correlation coefficient at the assumed level of $\alpha=0.05$.

\section{Findings}

As far as the general characteristics of behavior patterns are concerned, it has been noted that the four components (power range, power distance, the basis of manager's power, and information selection) are dominated by behavioural patterns defined as contemporary. Statistical analysis has shown that there is a link between these components and patterns of behavior.

However, it is noted that most respondents (80\%) to these patterns include: the method of selection of information that is a way of communication between managers and employees and the range of power (61.6\%). They represent more than half, and almost $2 / 3$ of indications.

On the other hand, in the case of the component - the degree of stability of power - no significant statistical differences were noted $(\mathrm{p}=0.7)$, and the dominant pattern of behavior was the traditional pattern.

The data allowing for the assessment of the link between components of the manager-employee relationship and behavior patterns is shown in the table below (Table 2).

\begin{tabular}{lcccc}
\hline \multirow{2}{*}{ Criterion } & \multicolumn{3}{c}{ Patterns of behaviour } & \multirow{2}{*}{ P } \\
\cline { 2 - 4 } & Traditional & Contemporary & Future & \\
\hline Scope of power & $16.4 \%$ & $61.6 \%$ & $22 \%$ & .000 \\
\hline Power distance & $11.8 \%$ & $50.4 \%$ & $37.9 \%$ & .000 \\
\hline Basis of manager's power & $27.4 \%$ & $46.4 \%$ & $26.2 \%$ & .003 \\
\hline Method of selecting information & $11.3 \%$ & $80 \%$ & $8.7 \%$ & .000 \\
\hline Degree of stability of power & $81.3 \%$ & $13.7 \%$ & $4.9 \%$ & 0.7 \\
\hline p- probability in chi-square independence test; - statistically significant correlation $(\alpha=0.05)$ \\
\hline
\end{tabular}

Turning to the detailed analysis, the following results will be presented concerning the components and diversity of patterns of behavior depending on the individual's position in the organizational structure against the background of official business relationship in the manager-employee setup. The first is the power range (Table 3 ).

The results show that in the case of a pattern of behavior and the scope of power exercised by the manager and the employee (Table 3), there is no apparent

PATTERNS OF
BEHAVIOUR IN THE MANAGER-EMPLOYEE

Izabela Bednarska-Wnuk 
Table 3.

Scope of power and patterns of behaviour

Source: own study based on empirical research.

Table 4.

Power distance and patterns of behaviour

Source: own study based on empirical research.

\begin{tabular}{lccc}
\hline $\begin{array}{l}\text { Location in the } \\
\text { relationship }\end{array}$ & Traditional & Patterns of behaviour $(\mathbf{p = 0 . 0 0 0}) *$ \\
\cline { 2 - 4 } Contemporary & Future \\
\hline Manager & $3.2 \%$ & $41.8 \%$ & $55 \%$ \\
\hline Employee & $13.9 \%$ & $53.7 \%$ & $32.5 \%$ \\
\hline $\begin{array}{l}\mathrm{p}<0.001 * ; \mathrm{p}-\text { probability in chi-square independence test } ;- \text { statistically significant correlation } \\
(\alpha=0.05)\end{array}$ & & \\
\hline
\end{tabular}

domination of one of the patterns of behavior. While managers declare in this regard behavioural patterns defined as future (55\%), employees consider them to be decisively contemporary $(53.7 \%)$ - democratic. Both the managers and the employees were the least likely to declare that the power of managers was of a traditional character, directed at subordination of the employee and his obedience. It should be noted that in the case of managers, this is a small percentage of indications (3.2\%).

The results concerning power distance between managers and employees and patterns of behavior present themselves quite differently (Table 4).

\begin{tabular}{lccc}
\hline \multirow{2}{*}{$\begin{array}{l}\text { Location } \\
\text { in relationship }\end{array}$} & Traditional & Contemporary & Future \\
\cline { 2 - 4 } Manager & $10.9 \%$ & $64.6 \%$ & $24.5 \%$ \\
\hline Employee & $18.1 \%$ & $61.3 \%$ & $20.6 \%$ \\
\hline $\begin{array}{l}\mathrm{p}<0.001^{*} ; \mathrm{p} \text { - probability in chi-square independence test; }- \text { statistically significant correlation } \\
(\alpha=0.05)\end{array}$ & & & \\
\hline
\end{tabular}

Results for this component indicate the presence of statistically significant differences $(\mathrm{p}=0.000)$. Both managers $(64.6 \%)$ and employees $(61.3 \%)$ most often point to contemporary patterns of behaviour in which the distance of power is small and based on mutual amicable relations. The employees have a greater degree of freedom and responsibility in the decision-making process than the employees representing the traditional pattern of behaviour; however they are not independent in that regard.

As regards the next component, the basis the manager's power (Table 5), it should be noted that the majority of both managers (48.9\%) and employees $(46.5 \%)$ declare that the authority of the manager in the examined organizations results primarily from his possession of high qualifications. This is the basis of the pattern of behaviour of the contemporary type. Nonetheless, differences in other patterns of behavior are observed in both groups. The managers $(29.5 \%)$ more often than the employees $(24.6 \%)$ declare that the manager's power is 
based on his knowledge and skills, which are characteristic of future behavioural patterns. On the other hand, formal authority (the basis of the pattern of traditional behavior) is more often declared by employees (28.9\%) than managers $(21.6 \%)$. The differences are statistically significant $(\mathrm{p}=0.003)$.

\begin{tabular}{lccc}
\hline \multirow{2}{*}{$\begin{array}{l}\text { Location } \\
\text { in relationship }\end{array}$} & \multicolumn{3}{c}{ Patterns of behaviour $(\mathbf{p = 0 . 0 0 3}) *$} \\
\cline { 2 - 4 } & Traditional & Contemporary & Future \\
\hline Manager & $21.6 \%$ & $48.9 \%$ & $29.5 \%$ \\
\hline Employee & $28.9 \%$ & $46.5 \%$ & $24.6 \%$ \\
\hline
\end{tabular}

$\mathrm{p}<0.001 * ; \mathrm{p}-$ probability in chi-square independence test; - statistically significant correlation $(\alpha=0.05)$

Similar correlations in the discussed behavioural patterns are noted in the next table (Table 6) regarding the method of selecting information according to the perception of the manager and employee.

\begin{tabular}{lccc}
\hline \multirow{2}{*}{$\begin{array}{l}\text { Location } \\
\text { in relationship }\end{array}$} & Traditional & Patterns of behaviour $(\mathbf{p = 0 , 0 0 0}) *$ \\
\cline { 2 - 4 } Manager & $4.8 \%$ & $89.3 \%$ & Future \\
\hline Employee & $12.8 \%$ & $78.1 \%$ & $5.8 \%$ \\
\hline $\begin{array}{l}\mathrm{p}<0.001 * ; \\
(\alpha=0.05)\end{array}$ & & $9.1 \%$ \\
\hline
\end{tabular}

PATTERNS OF BEHAVIOUR IN THE MANAGER-EMPLOYEE

Izabela Bednarska-Wnuk

\section{Table 5.}

The basis of manager's power and patterns of behaviour

Source: own study based on empirical research.

Table 6.

Method of selecting information and patterns of behaviour

Source: own study based on empirical research.

Studies show that there is a link between the pattern of behavior and the method of selecting information by the manager and employee $(p=0.013)$. A dominant behavioural pattern in both groups of workers is contemporary behavior. However, looking at the results in each group, it appears that employees more often than managers pointed out that the method of selecting information is done exclusively by the manager. It is $12.8 \%$ indications and $4.8 \%$ respectively. It is also worth noting that a similar distribution of variables is noted for future behavioural patterns. Relatively more often employees than managers believe that the selection of information in an organization is made primarily in an independent way by the employee, which is the basis of the pattern of behavior of the future.

Regarding the degree of stability of power the connection between this component and the pattern of behavior is not observed $(p=0.7)$ (Table 7).

The results of the study show that regardless of the location of the individual in the organizational structure the patterns of traditional behavior predominate. It is $81.3 \%$ of indications for managers and $75 \%$ for subordinates. Regardless of 
Table 7.

Degree of stability of power and patterns of behaviour

Source: own study based on empirical research.

\begin{tabular}{lccc}
\hline \multirow{2}{*}{$\begin{array}{l}\text { Location } \\
\text { in relationship }\end{array}$} & \multicolumn{3}{c}{ Patterns of behaviour $(\mathbf{p = 0 . 7}) *$} \\
\cline { 2 - 4 } Manager & $81.3 \%$ & Contemporary & Future \\
\hline Employee & $75 \%$ & $13.7 \%$ & $4.9 \%$ \\
\hline $\begin{array}{l}\mathrm{p}<0.001 * ; \\
(\alpha=0.05)\end{array}$ & $16 \%$ & $9 \%$ \\
\hline
\end{tabular}

the researched group, the least common pattern of behavior for determining the degree of stability of power is the future type.

\section{Discussion of research findings and the conclusions}

The categories of relationship between managers and employees distinguished in the article proved to be almost homogeneous in explaining varied behavior in this regard. Significant statistical correlations were recorded only with respect to four components: scope of power, power distance, basis of manager's power, and method of selecting information. No such dependence was confirmed in the case of the degree of power stability.

The results thus obtained allow only for partial acceptance of $\mathrm{H} 1$, indicating that there is a relationship between patterns of behavior and components of relationship between managers and employees. Similarly, regarding hypothesis H2 indicating that in Polish organizations dominant are contemporary patterns of behaviours in relationships between managers and employees the same correlations have been observed. In reference to the hypotheses above, it should be noted that as indicated by the results of empirical research, the dominant pattern of behaviours in relations between managers and employees are patterns of behavior of the contemporary type. Such data was obtained for the components: scope of power, power distance, and basis of manager's power and method of selecting information. In the case of the degree of stability of power - the characteristic pattern of behaviour is the traditional pattern.

Nevertheless, conformity depending on the individual's position in the organizational structure against the background of official business relationship from both the manager and employee has only been obtained for four components: power distance, the basis of the manager's power, degree of stability of power and the method of selecting information, although slight differences in responses of individual categories of employees have also been observed. On the other hand, in the component scope of power, the answers received from managers and employees are definitely differentiated.

In Polish organizations the scope of power is above all democratic. Differences, however, are noted in the responses received from managers and employees. 
Managers believe that the scope of power they possess is characteristic for the pattern of future-type behaviour, the so-called Affiliative. They are convinced that they encourage their employees to be autonomous in the decision-making process, thus ensuring a sense of security, certainty and worker integration.

Employees, on the other hand, think that this scope is typical of a pattern of behavior defined as democratic, favouring the so-called democratic coordination (Sikorski, 2010). This is due to the small distance of power, which forms the basis of civil society and fosters values such as individualism, freedom, selfrealization, adaptability, inner sense of control, positive self-esteem, proactivity and learning (Czajkowska, 2016). Employees do not feel like the so-called Cogs in the machine, they have some margin of freedom, so they can feel as part of a given organizational system and be the one responsible for creating the organization in which they are employed. On the other hand, however, this is limited autonomy because, as the employees claim, their managers have an influence on the final decision in the organization.

Regarding power distance both managers and employees agree that it is low. It means first and foremost an amicable relationship. Low power distance is also conducive to the common formulation of goals, consistent with their achievability and acceptability. In this situation, an important element in a relationship between managers and employees should be to build an organizational commitment that can help in collectively setting goals. The management should therefore take care of their employees by creating a suitable working atmosphere, because according to Z. Mikołajczyk the intended goals are achieved primarily through the skilful use of human capital (Błaszczyk, 2005).

Both low power distances revealed in empirical research as well as a scope of power of democratic or afiliative type should foster the development of a mentoring relationship between managers and employees. Such a relationship helps not only to acquire new knowledge or to systematize the „old" one but above all promotes succession in the organization and later development of a partnership that is usually built for a long time.

Fitting into this context are the successive results of research relating to the degree of stability of power which shows traditional patterns of behavior. As the managers indicate, they are employed in organizations primarily for an indefinite period. This is confirmed also by employees. This means that the manager performs his function ,,perpetually”. Probably the organization when deciding on this form of employing managers wants to give them a sense and a guarantee of security, increase their loyalty and commitment through longterm participation of managers in the organization. On the other hand, this limits the degree of flexibility of managers in choosing the place and time of work. This is also illustrated by the small number of indications concerning hiring the managers by the organization in the framework of a managerial contract, which
PATTERNS OF BEHAVIOUR IN THE MANAGER-EMPLOYEE

Izabela Bednarska-Wnuk 
PATTERNS OF BEHAVIOUR IN THE MANAGER-EMPLOYEE

Izabela Bednarska-Wnuk is more flexible than a contract of employment resulting from the Labour Code. In addition, it allows greater independence and discretion in decision-making and makes remuneration dependent on performance (Bednarska-Wnuk, 2016).

On the other hand, with respect to the basis of the manager's power, it was observed that both managers and employees in their majority agree on the existence of a contemporary pattern of behavior, i.e. the formal authority of the manager and the relevant competences he holds. For the respondents, what really matters is the official status of the manager in the organizational hierarchy and his substantive and managerial competencies. According to the respondents, the actual power of manager contributes first and foremost to shaping the right atmosphere in the workplace and building a good relationship based on long-term participation of employees in the organization.

However, in this component we recognize the diversity of responses in other variants. Managers, more notably than employees, point out that the basis for their power is only their knowledge and skills, and they do not identify it with their own status. This situation is likely to be interpreted by the lack of identification of managers with the function or role they play in the organization. Perhaps they do not realize that their realization is related to a specific position in the organizational structure or the power has been given to them, e.g. through delegation, and they are not assigned to a particular job position. On the other hand, employees more often than managers perceive the manager only in the context of a particular place in the hierarchy of the organization. This is probably due to the fact that employees do not identify the managers through the prism of their real, informal authority, depending primarily on his or her leadership style, which consists of personality traits, beliefs, attitudes, skills, abilities, experience and knowledge (hidden and accessible) but only by virtue of the managerial position they occupy. The data obtained is therefore not very optimistic, because the perception of managers by employees is characterized by an asymmetric concept of power typical of traditional organizations, whose primary task was to reduce by the manager the uncertainty among employees. The manager was credited with activity, creativity and pro-innovativeness, whereas employees were merely passive and obedient.

In this component, however, it can be considered satisfactory that this variation is small.

An important criterion for differentiating patterns of behavior is also the way of communication between managers and employees. Empirical research shows that primarily managers do not hold any information to themselves, treating the employee as an autonomous individual capable of independently collecting and selecting information about the organization. This is confirmed by employees. This is probably due to the belief that managers do not know what information and to what extent will turn out to be useful to employees, so they should be 
themselves depositors of organizational knowledge. Besides, the more they will be equipped with the given knowledge, the bigger chance the organization will have not only to survive and develop, but also to achieve success in the long run. On the other hand, the basis for functioning of the contemporary individual in the work situation should be their desire to acquire and supplement their own knowledge.

Relationships between managers and employees are an essential part of an organization, influencing its functioning, and developing specific patterns of behavior. Not only do they help to achieve organizational goals, streamline employee work, create a culture of trust, but also they influence employee attitudes and behaviours in the emotional, affective and cognitive domains.

In conclusion, it should be emphasized that the presented results of the research, resulting from the accepted theoretical construct (traditional, contemporary, and future patterns of behavior) have some limitations. Not all of the variables describing the discussed relations and constituting these formulas were taken into account (due to quantitative restrictions) and subjected to thorough operationalisation. Although, those presented in this article are already permanently fixed in the theoretical layer (Sikorski, 1999). Therefore, it seems that other variables, such as individual variables or environmental variables should be included in the research in this field.

In addition, it should be noted that the collected data and conclusions come from Poland and need not be confirmed in other countries.

These limitations may, however, be an incentive to undertake further research in this field, both in the theoretical and empirical layers, in order to thoroughly study patterns of behavior for the area of relations between managers and employees.

\section{Notes}

[1] The project has been financed by the National Science Centre under DEC-2013/09 / B / HS4 / 02722.

[2] The study was conducted on a representative sample of companies employing at least 50 employees. The sample was randomly selected within the layers based on the size of employment (medium / large) and business line (trade, industry and services). Due to over representability in the sample of traders and underrepresentation of services, and due to the diverse responsiveness of particular groups of companies, the sample structure was aligned with the structure of population of medium and large enterprises in Poland using analytical weights. The study was carried out by the ARC Research and Market Research Institute, based on the methodology developed by the research team of the Faculty of Management, University of Lodz. 
PATTERNS OF BEHAVIOUR IN THE MANAGER-EMPLOYEE

Izabela Bednarska-Wnuk

\section{References}

Amarjits, G. S. (2008), “The role of trust in employee-manager relationship", International

Journal of Contemporary Hospitality Management, Vol. 20 No. 1, pp. 98-103. DOI: $10.1108 / 09596110810848613$

Ayache, M., Laroche, H. (2010), "La construction de la relation managerial: Le manager face à son supérieur. Managers and their bosses: building the managerial relationship", Revue Française de Gestion, No. 203, pp. 1-10.

Bednarska-Wnuk, I. (2016), "Wymiar relacje przełożony-podwładny", in: Januszkiewicz, K. et al., (Eds.), Wielowymiarowa Analiza Zachowań Organizacyjnych [WAZO] w polskich przedsiębiorstwach. Wyniki badań empirycznych, Wydawnictwo Uniwersytetu Łódzkiego, Łódź, pp. 147-180.

Błaszczyk, W. (Ed.), (2013), Metody organizacji i zarzadzania. Kształtowanie relacji organizacyjnych, Wydawnictwo Naukowe PWN, Warszawa.

Czajkowska, M. (2016), Rozproszenie władzy w uczelniach publicznych jako odpowiedź na wyzwania współczesności, Wydawnictwo Uniwersytetu Łódzkiego, Łódź.

Jabłoński, M. (2012), "Klasycy organizacji a wybrane aspekty zarządzania kompetencjami", in: Mikuła, B., (Eds.), Historia i perspektywy nauk o zarzqdzaniu, Wydawnictwo Uniwersytetu Ekonomicznego w Krakowie, Kraków, pp. 23-31.

Januszkiewicz, K., Bednarska-Wnuk, I., Czajkowska, M., Kołodziejczak, M., Michalak, J., Świątek-Barylska, I., Zalewska-Turzyńska, M. (2016), Kwestionariusz WAZO metodyka i narzędzie badawcze, Wydawnictwo Uniwersytetu Lódzkiego, Lódź.

Januszkiewicz, K. i zespół (2012), Zachowania ludzi w organizacji. Uwarunkowania i kierunki ewolucji, Wydawnictwo Uniwersytetu Łódzkiego, Łódź.

Juchnowicz, M. (2012), Zaangażowanie organizacyjne. Sposoby oceny i motywowania, Polskie Wydawnictwo Ekonomiczne, Warszawa.

Kożusznik, B. (2014), Zachowania człowieka w organizacji, Polskie Wydawnictwo Ekonomiczne, Warszawa.

Lewicka, D. (2013), "Wpływ zaufania wertykalnego na zaangażowanie organizacyjne pracowników”, in: Czajkowska, M., Januszkiewicz, K., Kołodziejczak, M., Zalewska-Turzyńska, M., (Eds.) Uwarunkowania zachowań ludzi w organizacji, Folia Oeconomica 282, Acta Universitatis Lodziensis, Wydawnictwo Uniwersytetu Łódzkiego, Łódź, pp. 179-186.

O'leary, R. S., Pulakos, E. D. (2011), "Managing performance Through the ManagerEmployee Relationship", Industrial \& Organizational Psychology, Vol. 4 No. 2, pp. 208-214.

Penc, J. (2007), Nowoczesne kierowanie ludźmi. Wywieranie wpływu i współdziałanie w organizacji, Difin, Warszawa.

Rakowska, A. (2007), Kompetencje menedżerskie kadry kierowniczej we wspótczesnych organizacjach Wydawnictwo Uniwersytetu M.C. Skłodowskiej, Lublin.

Rawlins, W. K. (1992), Friendship Matters: Communication, Dialectics, and the Life Course, NY: Aldine, Hawthorne.

Robbins, S. P., Judge, T. A. (2012), Zachowania w organizacji, PWE, Warszawa.

Sikorski, Cz. (2010), "Przywództwo emocjonalne a racjonalne w edukacji", in: Kwiatkowski S.M., Michalak J.M. (Ed), Przywództwo edukacyjne w teorii $i$ w praktyce, Fundacja Rozwoju Systemu Edukacji, Warszawa, pp. 25-46. 
Sikorski, Cz. (1999), Zachowania ludzi w organizacji, Wydawnictwo Naukowe PWN, Warszawa.

Stańczyk-Hugiet, E. (2010), “Czy ekonomia wiedzy powoduje zmianę roli menedżera?”, in: Listwan, T. (Ed.), Menedżer $w$ gospodarce opartej na wiedz, Prace Naukowe BEHAVIOUR IN THE MANAGER-EMPLOYEE Uniwersytetu Ekonomicznego we Wrocławiu, Nr 115, Wydawnictwo Uniwersytetu Ekonomicznego we Wrocławiu, Wrocław, pp. 678-687.

Świątek-Barylska, I. (2013), Lojalność pracowników wspótczesnych organizacji. Istota i elementy składowe, Wydawnictwo Uniwersytetu Łódzkiego, Lódź.

Szałkowski, A. (2006), Podstawy zarzadzania personelem, Wydawnictwo Akademii Ekonomicznej w Krakowie, Kraków.

Izabela Bednarska-Wnuk 